\title{
Interpreting forest diversity-productivity relationships: volume values, disturbance histories and alternative inferences
}

\author{
Douglas Sheil $^{1 *}$ (D) and Frans Bongers ${ }^{2}$
}

\begin{abstract}
Understanding the relationship between stand-level tree diversity and productivity has the potential to inform the science and management of forests. History shows that plant diversity-productivity relationships are challenging to interpret—and this remains true for the study of forests using non-experimental field data. Here we highlight pitfalls regarding the analyses and interpretation of such studies. We examine three themes: 1) the nature and measurement of ecological productivity and related values; 2 ) the role of stand history and disturbance in explaining forest characteristics; and 3) the interpretation of any relationship. We show that volume production and true productivity are distinct, and neither is a demonstrated proxy for economic values. Many stand characteristics, including diversity, volume growth and productivity, vary intrinsically with succession and stand history. We should be characterising these relationships rather than ignoring or eliminating them. Failure to do so may lead to misleading conclusions. To illustrate, we examine the study which prompted our concerns - Liang et al. (Science 354:aaf8957, 2016) — which developed a sophisticated global analysis to infer a worldwide positive effect of biodiversity (tree species richness) on "forest productivity" (stand level wood volume production). Existing data should be able to address many of our concerns. Critical evaluations will improve understanding.
\end{abstract}

Keywords: Causation, Correlation, Diversity, Inference, Productivity, Richness, Tree-growth, Wood-density

\section{Background}

An understanding of the relationships between plant diversity and vegetation productivity offers insight into plant communities and the goods and services they provide (Darwin 1859; Waide et al. 1999; MEA-team 2005; Braat and de Groot 2012; Harrison et al. 2014; Fanin et al. 2018). In recent decades these relationships have provoked much argument and ultimately this led to improved understanding through experiments with herbaceous communities (e.g., Naeem et al. 1994; Tilman et al. 1996). Nonetheless debate has persisted, from the past (Huston 1997; Hector 1998; Huston et al. 2000; Loreau et al. 2001; Wardle 2001), to the present (Sandau et al. 2017; Wright et al. 2017; Oram et al. 2018).

\footnotetext{
* Correspondence: douglas.sheil@nmbu.no

${ }^{1}$ Faculty of Environmental Sciences and Natural Resource Management (MINA), Norwegian University of Life Sciences (NMBU), Box 5003, 1432 Ås, Norway

Full list of author information is available at the end of the article
}

The relationship between forest diversity and productivity has generated particular interest given concerns over forest degradation and its implications for the global carbon cycle, water, climate and related processes and values (Nadrowski et al. 2010; Edwards et al. 2014; Mori et al. 2017). While large, long-term experiments appear the best way to infer causal relationships and are increasingly being implemented (Tobner et al. 2016; Verheyen et al. 2016; Fichtner et al. 2017; Bruelheide et al. 2019), they remain time-consuming and costly (Leuschner et al. 2009; Wang et al. 2016; Huang et al. 2018; Mori 2018). Furthermore, we must recognise when and how results from planted or modified forests provide insight into natural systems (and visa-versa). Given this context, field observations may also provide valuable insights.

Here, we note various challenges for field based studies under three headings: volume values, disturbance difficulties and inferential inquiries. Our review was stimulated by a high profile 84-author study (Liang et al. 
2016), that has already been cited nearly 400 times (Google Scholar January 2020). We use this study for illustration. We find broad lessons for future work and foresee good potential for progress.

\section{Challenges}

Volume values: wood volume growth $\neq$ productivity $\neq$ value production

Here we explain why changes in forest stand volume are neither a meaningful measure of ecological productivity nor of economic benefits nor of any other clearly defined values which we can identify. We start by considering wood volumes. Equal volumes of wood grown in different forests can differ in mass as mean wood densities vary within and among forests (Baker et al. 2004; Swenson and Enquist 2007; Slik et al. 2008). Species-specific wood densities vary from $0.1 \mathrm{~g} \cdot \mathrm{cm}^{-3}$ for Ochroma pyramidale (Cav. ex Lam.) Urb. (Malvaceae) to over 1.3 $\mathrm{g} \cdot \mathrm{cm}^{-3}$ for Guaiacum officinale L. (Zygophyllaceae) and Brosimum rubescens Taub. (Moraceae) (Praciak et al. 2013). Some fast-growing pioneer species possess naturally hollow stems (e.g., Cecropiaceae and Caricaceae).
These differences result in variations in mean stemweighted wood densities among forest communities that can vary over twofold in a given location (Slik et al. 2008).

Differences in wood density relate to various factors including soil conditions and drought tolerance, but also with each species' typical successional position and ability for rapid growth (van Nieuwstadt and Sheil 2005; Nepstad et al. 2007; Poorter et al. 2019). For example, in wet tropical forests when species are ordered from early through to late succession their characteristic wood densities generally increase and their maximum volume growth decrease (Ter Steege and Hammond 2001; Slik et al. 2008). Thus, mean (volume-, basal area- or stemweighted) wood density within any wet climatic region tends to be lower in the early stages of secondary regrowth forest when compared to a site comprising relatively undisturbed old growth. As a tree's carbon costs per unit wood volume are directly related to its wood density (King et al. 2006), volume growth rates also tend to be greater in (younger) post-disturbance forests than in late successional formations dominated by tree

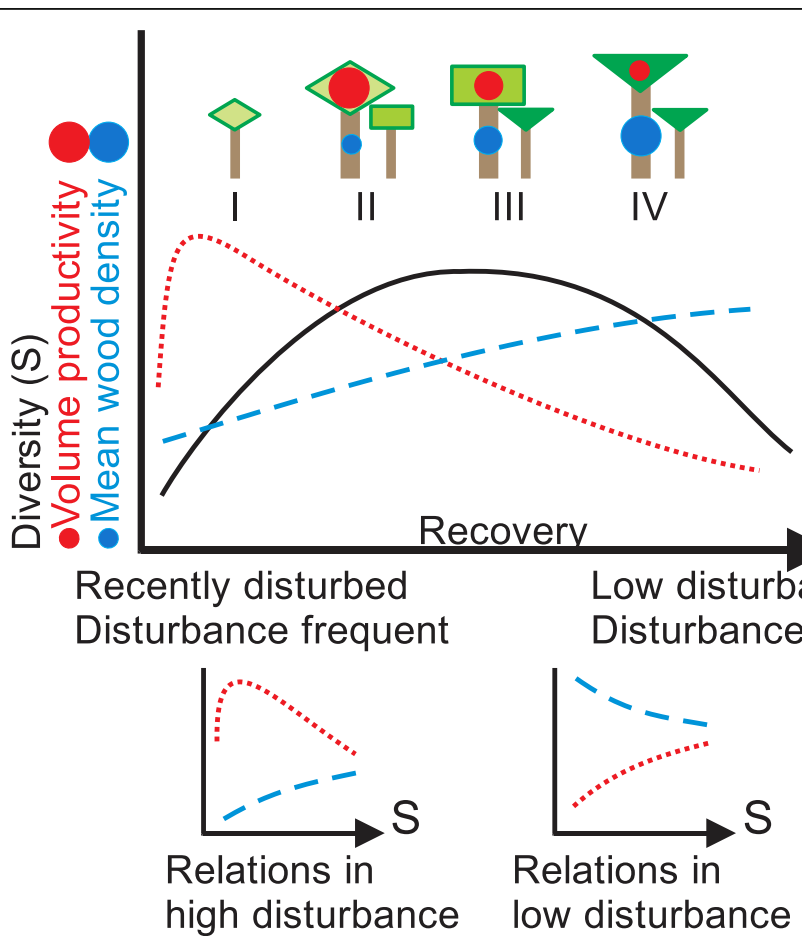

Fig. 1 Schematic example of how species diversity (S), volume production and mean wood density may co-vary with disturbance and recovery in an example wet forest. The top schematic shows four idealized stages in forest recovery (I-IV) comprised of three species: pioneer, early- and late-successional (after Connell 1978). These species possess characteristic volume-growths and wood-densities indicated by the relative size of the red and blue circles respectively on the adult trees. Species diversity in the four schematic successional stages shows a rise and fall with longterm forest recovery (a peak occurs between II and III when all three species have the potential to co-occur). The central graphic illustrates the rise and fall of diversity (continuous black line), declining volume growth (red dotted line), and increasing mean stand wood density (blue dashed line) with recovery (absence of disturbance) in a wet forest. The two lower figures show the potentially contrasting relationships between diversity, volume growth and wood density that may occur depending on the disturbance histories observed. This schematic is a stylized representation of patterns that will differ among locations (for example, wood densities may decline with succession in dry Neotropical forests) 
species with higher wood density (see blue and red lines in Fig. 1). Typical stand level biomass production changes with succession too. Contrasting patterns of volume growth and wood density may cancel to some degree, typically leading to a rapid early rise to reach high rates of stem biomass production in early succession and a gradual decline through mid- and late-succession (Lasky et al. 2014). In dry tropical forest contrasting trends can occur with denser wood found in early succession, and declining wood densities as the forest matures (Poorter et al. 2019)-whatever the underlying patterns, plot level wood density and disturbance histories are not independent.

Forest productivity is defined, measured and estimated, in many ways. All methods involve assumptions, approximations and potential errors and biases (Sheil 1995a, 1995b; Waring et al. 1998; Clark et al. 2001a, 2001b; Chave et al. 2004; Roxburgh et al. 2005; Williams et al. 2005; Litton et al. 2007; Malhi 2012; Sileshi 2014; Talbot et al. 2014; Searle and Chen 2017; Šímová and Storch 2017; Kohyama et al. 2019). Typically, in ecological studies, focused on forest stands (not individual trees), we are interested in net primary production (NPP) or major components of biomass such as above ground woody material-these expressed as mass per unit area per unit time. Large scale studies suggest that forest properties, notably stand age and biomass, explain much of the variation in NPP (estimated annual drymass biomass production of root, stem, branch, reproductive structures and foliage) while climate often has surprisingly little influence (Michaletz et al. 2014). Such patterns differ among forests, notably, biomass and biomass production tend to be closely correlated in early succession as a stand establishes and grows to fill space, but this relationship tends to weaken and reverse in advanced succession (Lohbeck et al. 2015; Prado-Junior et al. 2016; Rozendaal et al. 2016).

In some situations, changes in forest volume production may covary with changes in market values. This would be the case when timber of all sizes, species and qualities are bundled together, as may arise when a forest stand is being managed to produce wood fibre or charcoal-but this generalisation is at best an approximation and is seldom true. In most stands not all volume is equally valued or valuable. Sizes matters: only stems with sufficient size and good form yield high value saw logs or veneer. Furthermore, relatively few tree species have high commercial value, especially in the tropics (Plumptre 1996). After a disturbance, it will generally be quicker for a forest to recover in terms of volume of small stemmed pioneers (low value volume), than to regenerate large stems of valuable dense timbered species (high value volume). These preferences are why timber extraction in species rich forests is usually selective: targeting only large stems of certain species. For example, commercial exploitation in Gabon typically involves less than one tree per ha (e.g., average 0.82 according to Medjibe et al. 2011). Note that once the small numbers of valued stems are removed the value of the remaining stand is much lower despite maintaining a similar volume and diversity. Such selective impoverishment has been widespread. An example is the Caribbean regions where high-value mahogany (Swietenia macrophylla King Meliaceae), has long been sought, removed and depleted (Snook 1996). Even where there are opportunities to use a broad range of species, e.g., for charcoal, some stems are still likely to be treated separately as a result of their greater commercial value (Plumptre and Earl 1986).

These stem specific differences in value also explain why silviculture in mixed species forests aims not to improve overall stand volume growth (or diversity) but rather to favour the production of particular species (Dawkins and Philip 1998; Peña-Claros et al. 2008; Doucet et al. 2009). These differences also apply in low diversity systems. Consider a high value teak (Tectona grandis L.) forest and a nearby monoculture stand of an abundant weak hollow stemmed species such as Cecropia (Cecropia peltata L.): volume production in these two stands represents very distinct commercial values. We are unaware of any general studies that indicate that other forest derived values, such as non-timber products, conservation benefits or hydrological function, vary in a predictable manner with stand volume or productivity (or related measures). Indeed indications from studies of stand structure and other forest characteristics such as tree or mammal diversities or palm densities-though seldom examining volume or volume growth-suggest such relationships are unlikely (Clark et al. 1995; Beaudrot et al. 2016; Sullivan et al. 2017). Valid global relationships appear especially implausible. We cannot identify any clearly defined values that vary linearly with volume production.

\section{Disturbance difficulties: how histories influence stand properties}

Forests reflect their histories including past disturbances and subsequent recovery. These relationships remain central themes in forest ecology (e.g., Guariguata and Ostertag 2001; Sheil and Burslem 2003; Canham et al. 2004; Royo and Carson 2006; Ghazoul and Sheil 2010; Drake et al. 2011; Seidl et al. 2011; Ding et al. 2012; Gamfeldt et al. 2013; Chazdon 2014; Lasky et al. 2014; Rozendaal and Chazdon 2015; Scheuermann et al. 2018). Indeed, while themes have evolved, the importance of these temporal relationships has long been recognised in both temperate (for example, Transeau 1908; Gleason 1917; Tansley 1920; Phillips 1934; Clements 1936; Watt 
1947; Langford and Buell 1969) and tropical contexts (see, e.g., Richards 1939; Eggeling 1947; Greig-Smith 1952; Hewetson 1956; Webb 1958; Aubréville 2015). Even the first major treatise to examine tropical forests in a global manner, presented them in terms of succession and associated characteristics (Richards 1952). It is because of these somewhat predictable patterns, and the range of disturbance histories encompassed in most forest samples, that many stand properties co-vary; for example, stand turnover rates, wood density and treediversity (Sheil 1996; Slik et al. 2008). Similarly, because of such underlying relationships, we expect treediversity, productivity, and volume growth to co-vary with disturbance history.

Tree species richness typically rises in early succession as species accumulate, and, if conditions-permit, ultimately falls in later stages due to competition and the failure of shade-intolerant species to replace themselves (see black line, S, in Fig. 1). This "humped" or unimodal pattern is the basis for Connell's Intermediate Disturbance Hypothesis (Connell 1978, 1979; Sheil and Burslem 2003, 2013). Despite debate and frequent misrepresentation, there is general agreement that the original mechanisms proposed by Connell, involving competitioncolonization trade-offs among species, are valid and ecologically relevant (e.g., see Fox 2013a, 2013b; Sheil and Burslem 2013; Huston 2014). While other factors play a role too, disturbance dependent mechanisms often contribute to observed patterns of species diversity (Kershaw and Mallik 2013; Huston 2014).

When sampling and disturbance histories permit, both sides of the successional rise-and-fall in the species-richness pattern becomes evident. Consider Guyana, where some areas of forest possess a higher proportion of faster growing but light-timbered species whereas other, typically lower-diversity, forests possess more densetimbered, slow-growing species (Molino and Sabatier 2001; Ter Steege and Hammond 2001).

Sampling may not capture the full pattern. For example, evaluations of sites representing only the rising section of diversity and succession may be interpreted (incorrectly) as evidence against disturbance playing a positive role in maintaining diversity, when an absence of disturbance would nonetheless lead to a loss of species (for more detailed explanations please see Sheil and Burslem 2003).

Sometimes interpretations remain ambiguous. For example, a study of diversity and successional state across Ghana's forests found that while the predicted rise and fall diversity patterns were detected across all the major forest types, disturbance appeared to contribute more to maintaining diversity in drier than in wetter sites. The most mature (i.e. apparently old growth) forests found in these wetter sites maintained most (but not all) of the species found in less advanced sites (Bongers et al. 2009). Among drier sites, the most mature forests showed less diversity compared to younger sites. These results cannot distinguish whether other mechanisms contributed more to maintaining diversity in wetter (versus drier) forests or whether there was simply a paucity of sufficiently undisturbed (late successional) examples to show what happens under these conditions (Bongers et al. 2009).

So diversity tends to rise in early succession, reach a peak and may then gradually decline if there is little disturbance. What about volume growth and productivity? After an extreme event, volume and biomass production grow before levelling off and gently declining with stand age (Lorenz and Lal 2010; Goulden et al. 2011; He et al. 2012; Lasky et al. 2014). This can be understood as a result of the initial influx and establishment of fast growing (in wet forest typically low-wood-density) early successional pioneer species, with the forest becoming more efficient at capturing light as the more shade-tolerant, later-successional species also become established. The decline likely results from the reduced efficiency (per unit area) of light interception and photosynthesis of larger (versus smaller) trees (Yoder et al. 1994; Niinemets et al. 2005; Nock et al. 2008; Drake et al. 2011; Quinn and Thomas 2015) and the proportion of energy invested in woody growth (Kaufmann and Ryan 1986; Mencuccini et al. 2005; Thomas 2010).

The consequence of these successional trends is that various stand properties tend to co-vary (see Fig. 1). Depending on if and how the rising and falling section of the relationships are represented in the data, this covariation alone can result in an increase (or decrease) in stand-volume-growth, or productivity, with increasing diversity (see lower insets in Fig. 1). Consider an old-growth forest disturbed by some event that opens the canopy (a windstorm or timbercutting): fast growing pioneer species that were not previously present can now establish, boosting species numbers and volume growth. Such patterns neither prove nor disprove that diversity bolsters productivity but they show how correlations can arise independently of such relationships.

Can we avoid the complications created by disturbance histories by using basal area as a proxy and including it as a random variable in our analyses? No-while basal area change can be useful as an immediate measure of disturbance there is no simple, one-to-one relationship between basal areas and successional stages or related processes. Partial basal area values can arise in many ways: for example, a value of $80 \%$ might result after several years of recovery following a large disturbance (a reduction to less than 50\%), more recently after a lesser one (a reduction to $75 \%$ ), or a cumulative consequence 
of many small events without sufficient time to recover (each event leading to only a few percent decline). In any case, few stands result from a single disturbance to an otherwise never-disturbed old-growth forest. Most experience a complex mixture of intrinsic and extrinsic disturbances of varying forms and magnitudes that to some degree decouples basal area from composition and other successional responses. Also, while basal area typically recovers quite rapidly this is not necessarily true for other stand characteristics (Rozendaal et al. 2019). Comparisons of regrowth and old-growth show how idiosyncratic recovery is, with many plots surpassing predisturbance reference levels of species richness in less than a decade while others don't reach it in more than one century (see, e.g., Martin et al. 2013). Relatively rapid, but variable, recovery of species richness was also reported from a recent review of Neotropical sites (Rozendaal et al. 2019). For biomass, there is also variation with some sites recovering within a couple of decades and others not reaching original levels in 80 years (Martin et al. 2013; Poorter et al. 2016). Composition typically remains distinct for longer-decades or even centuries (see, e.g., Chai and Tanner 2011; Rozendaal et al. 2019).

How are basal area and successional state related? As basal area and compositional maturity both decline as a result of disturbance, and recover subsequently, we might expect that these variables would track each other yielding a clear positive relationship, but this is not necessarily the case. In forests subjected to repeated disturbance, basal area can become decoupled from composition. For example, consider any system in which stand basal area and composition (percentage of late successional species) both recover after disturbance, and in which stems can persist for decades, and subject it to just one disturbance: basal area and (some years later) composition will subsequently recover towards their pre-disturbance levels (Fig. 2 upper panel). Now subject this same system to stochastic disturbances over an extended period: if the disturbance events are sufficiently frequent and severe, any relationship between basal area and composition is readily obscured (see Fig. 2 lower panel). Our point here is not to identify specific conditions under which such decoupling occurs in a specific model-this will reflect many factors including both the vegetation persistence and response lag-times as well as details of the disturbance-but to recognise that it can plausibly do so in a wide range of cases that arise in nature. Studies of managed forests also show that, while some patterns appear typical, the nuances of stand structure, age and productivity cannot be readily captured in any one variable (Liira et al. 2007). For such reasons incorporating basal area, or similar univariate stand properties, in the analysis may influence results but not remove the impact of disturbance.

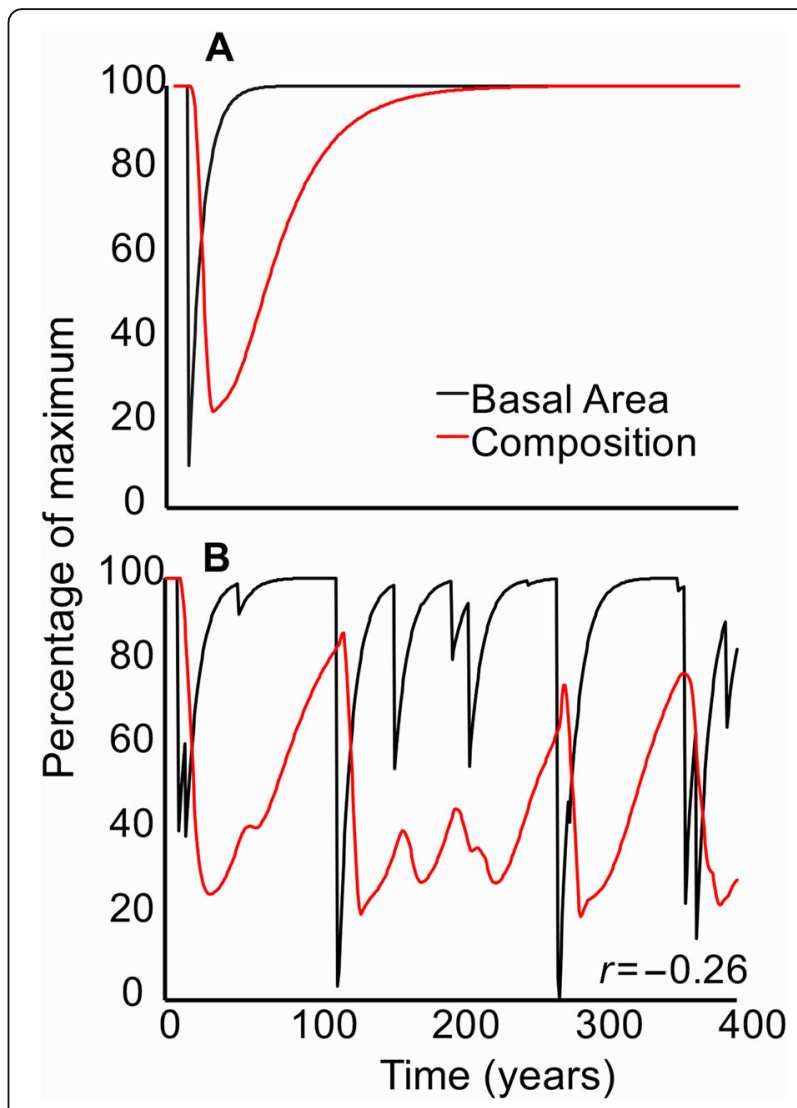

Fig. 2 Outputs from a simple simulation model in which "basal area" and "composition" (percentage late successional species) both recover after disturbance. Composition involves persistence (the composition of surviving stems is unchanged immediately following disturbance), lagtimes and integration (the composition of recruits depends on canopy openness over previous years with more early successional species surviving in more open conditions). a shows the simulated response over 400 years where a single event removes $90 \%$ of basal area in the tenth year. b shows an example where, from year ten onwards, disturbances occur with a $5 \%$ probability each year. If a disturbance event occurs it removes a randomly generated fraction of basal area between 0 to 100\% (skewed to lower values). While both basal area and our measure of composition decline with disturbance, and increase with recovery, the Pearson product moment correlations ( $r$ ) between these variables are often negative (as in the example)

We are not claiming that succession provides a simple explanation of community change. Succession is only predictable in part (Norden et al. 2015). Patterns can be complex, context dependent and idiosyncratic (Chazdon 2003; Ghazoul and Sheil 2010; Sheil 2016; Bendix et al. 2017). They may include alternative pathways, or stall (Royo and Carson 2006; Norden et al. 2011; Tymen et al. 2016; Arroyo-Rodríguez et al. 2017; Ssali et al. 2017). Nonetheless, these patterns-however manifested-may be sufficiently consistent to influence statistically defined relationships among stand properties like diversity, volume growth and productivity. 
We cannot understand forests separate from their disturbance histories. The importance of sampling and context mean that generalisations may not be readily transferrable from one data set to another unless we know, and can account for, such histories. Thus, we need to consider these factors explicitly and be wary of generalisations that neglect them. Simple fixes are unlikely to be effective.

\section{Inferential inquiries: conclusions about causation}

Determining causality has been a theme in the philosophy of science since Aristotle (Holland 1986) - and has fuelled analytical innovations concerning the ability to infer and assess causal effects using both experimental and non-experimental observations (e.g., Freedman 2006; Cox 2018). While some issues remain contested (see, e.g., Pearl 2018) there is broad consensus that correlation alone should not be assumed as strong evidence of causation in non-experimental data (Höfer et al. 2004) and statistical methods used to "draw causal inferences are distinct from those used to draw associational inferences" (Holland 1986). While many will consider this obvious, the prevalence and persistence of the problem justifies concern.

So, if we find it, how should we interpret a positive correlation between species diversity and productivity? Potential explanations abound. Maybe greater diversity causes greater productivity. This could result from a niche interpretation in which a greater diversity of species use resources more effectively due to their complementary use of resources in space and time (del Río et al. 2017; Williams et al. 2017; Lu et al. 2018). It could also result if species which occurred at lower abundances (as occurs for an average species in richer communities) tend to have greater productivity than common species, through "rare species advantage" (Bachelot and Kobe 2013) permitting better growth and productivity than in lower diversity systems (Mangan et al. 2010; LaManna et al. 2016). It can also arise through a "sampling effect" in which communities with more taxa are more likely to include high-productivity species (Huston 1997).

Maybe, rather than diversity facilitating productivity it is productivity that facilitates diversity (Waide et al. 1999; Coomes et al. 2009; Jucker et al. 2018). For example, there are data indicating that taller forests occur on richer, presumably more productive, soils (at least in Africa and Asia, Yang et al. 2016), and also that, all else being equal within a given region, taller forests tend to contain more species than shorter forests (Huston 1994; Duivenvoorden 1996).

A positive correlation could also result from shared causes. For example, both diversity and productivity may vary with climate, soil nutrients or disturbance histories (see previous section). Stem densities and numbers are also a plausible explanation, as the count of individuals is an upper bound to the possible number of species (Hurlbert 1971; Colwell et al. 2012) and denser forest also tends to be more productive (Michaletz et al. 2014) at least in early succession (Lohbeck et al. 2015; PradoJunior et al. 2016; Rozendaal et al. 2016). In any case, stem numbers and related measures can vary due to sampling noise making any such recorded variables nonindependent-with such influences being particularly important when plots are small (Colwell et al. 2012). Positive correlations could arise from more complex relationships too, for example, when observations span only the left-hand (e.g. low productivity) part of a unimodal rise-and-fall relationship where productivity determines diversity (Tilman 1982), or result from more complex sampling effects (see, e.g., Waide et al. 1999; Chase and Leibold 2002).

Explanations and mechanisms are not exclusive and may be valid concurrently. Grassland studies indicate that differences in diversity can be simultaneously a cause and a consequence of differences in productivity (e.g., Grace et al. 2016).

We should also expect interactions amongst causes, effects and mechanisms. For example, many of the underlying processes will respond to climate (Fei et al. 2018). Or, to take a more specific example, we know that the responses and the effect of disturbance will vary with the local species-and we know that this can be determined by context. Consider, for example, the forests of the islands of Krakatoa versus the Sumatra mainland where though many tree species are shared, many mainland species, including the regionally dominant dipterocarps have failed to re-establish on the islands since the 1883 eruption due to dispersal limitation which has limited the convergence of the regrowth forest (Whittaker et al. 1997). Mechanisms vary too. For example, niche complementarity can vary with composition, context (Fichtner et al. 2017) and disturbance history in both temperate and tropical forests (Lasky et al. 2014; Gough et al. 2016).

We don't dispute that diversity generally contributes to increased productivity. That has been demonstrated many times in various systems including forests (Wang et al. 2016; Fichtner et al. 2017; Huang et al. 2018; Mori 2018). But that doesn't mean that this contribution alone determines the relationship between tree diversity and stand productivity. Correlations arise in many ways. Recognising the multiple processes that might generate and influence a correlation between diversity and productivity is essential for correct interpretation.

\section{Case study}

Liang et al. (2016) presented a global evaluation of tree diversity versus what they called "productivity" and inferred that greater diversity leads to greater productivity. They use this result to estimate the economic value of the diversity in forests. By way of context, they argued the need for "accurate valuation of global biodiversity". 
They quantified plot level tree species richness and volume productivity using 777,126 tree plots from 44 countries (the plots contain more than 30 million trees from 8737 identified species, coverage is uneven with tropical forests being poorly represented). They used various analytical approaches, including spatially constrained resampling and regression. From these, they inferred a worldwide positive effect of tree species richness on tree volume productivity that varies somewhat among regions. They used the derived relationship to estimate that the economic value of biodiversity in maintaining commercial forest productivity is more than double the total estimated cost of effective conservation of all terrestrial ecosystems (between 166 billion and 490 billion USD $\$ \cdot \mathrm{yr}^{-1}$ ). So how does this study measure up against our concerns?

\section{Volume values}

Liang et al. (2016) estimated changes in stem volume $\left(\mathrm{m}^{3} \cdot \mathrm{ha}^{-1} \cdot \mathrm{yr}^{-1}\right)$ as their measure of productivity and associated values. This measure contrasts with more conventional assessments of productivity that consider rates of change in biomass or carbon stocks. Liang et al. defend their choice by noting that volume is easier to estimate and is sufficient for their goal of summarising overall forest product values. Assuming a linear relationship between stem volume productivity and "values" (we remain unclear how these values are circumscribed and what they represent-see below) they use their relationships to estimate that an evenly distributed worldwide decrease of tree species richness of $10 \%$ would reduce volume, and associated value, productivity by 2.1 to $3.1 \%$ which, using two alternative values for forest production, equates to costs of USD\$ 13-23 billion per year. Volume growth is a poor proxy for timber value or carbon gains. Questions over which values might relate adequately to volume growth, and how, were debated previously. We will not repeat the details here (see, Barrett et al. 2016; Paul and Knoke 2016). Our view is that the implied values are ill-defined and the underlying assumptions and relationships undemonstrated. We highlight that volume increment does not provide a meaningful measure of primary productivity nor does it equate to an increment in economic values.

\section{Disturbance difficulties}

Liang et al. (2016) sought to eliminate the influence of disturbance by excluding plots where forest harvest had exceeded $50 \%$ of stocking volume and by including basal area as a random variable in their analyses. Having taken these steps, they gave disturbance and recovery no further consideration. This is inadequate. There is no evidence that disturbance effects diversity and productivity only once stocking is reduced by over $50 \%$, or that basal area is a valid and consistent-let alone sufficient-measure of succession (see previous discussions, and Fig. 2). The patterns they observe remain influenced by disturbance histories (as suggested in Fig. 1).

\section{Inferential inquiries}

Liang et al. (2016) find that, in general, higher diversity is associated with higher productivity. They interpret this as showing that greater diversity causes greater productivity and favour a niche interpretation. Indeed, this causation is assumed when they define the biodiversity-productivity-relationship as "the effect of biodiversity on ecosystem productivity". While such a relationship likely exists, their estimates should be treated with caution as alternative influences and explanations remain unexamined.

\section{Discussion and conclusions}

We have highlighted pitfalls in the study of forest diversity and productivity and illustrated our concerns by showing that these faults are manifested in a highly cited, multi-author study in a prestigious journal. These pitfalls include the use of volume production as a measure of productivity and value; the neglect of disturbance histories; and interpreting a simple correlation as causal when other explanations exist. The problems would presumably be recognised and rectified given time, but in the meantime we observe these studies being cited as if they are established fact (see, e.g., Bruelheide et al. 2019). In fairness, we note that the problems we have detailed may not be common, and there are many more nuanced analyses in the literature (e.g., for USA forests, Fei et al. 2018). Nonetheless, that may change if flawed studies become influential. For example, we note that Luo et al. (2019), like Liang et al. (2016), adopt the same implicit causal assumptions and disregard alternatives. Forewarned is forearmed.

Our list of pitfalls and concerns is not exhaustive (see, e.g., Dormann et al. 2019). Other studies raise other concerns too. For example, one reviewer suggested that we assess some studies using European forest data: Jucker and colleagues concluded that aboveground stand biomass growth (not volume as in Liang et al. 2016), increased with tree stand species richness (Fig. 7 in Jucker et al. 2014a and Fig. 2 and Figure S11 in Jucker et al. 2016). Yet they also determined that neither stand basal area nor stem densities varied with species richness (Fig. S7 in Jucker et al. 2015 and Fig. S4 in Jucker et al. 2016) and indicated that neither mortality nor thinning varied with richness too (Jucker et al. 2014b, 2015). This raises questions concerning how biomass production can vary if basal area, mortality and thinning do not. As the reviewer noted, the claim that mortality does not vary with diversity may be the critical issue given results from other studies (for example, Liang et al. 2005, 2007; Lasky 
et al. 2014). Furthermore, the researchers suggested that canopy packing increased in response to species mixing and disregarded silvicultural activities as a possible cause (Jucker et al. 2015). However, such packing can be promoted by thinning: foresters often wish to ensure retained crop trees have the space and conditions for good growth and identify and remove trees that interfere with others or are likely to be supressed. Even if limited thinning occurred early in the stands' development the effects could be long lasting and could subsequently appear to result from "species mixing" alone. We cannot judge these suggestions from available information. Clearly there is much still to clarify and in the meantime all such studies should be treated with skepticism-even if they are published in reputable journals.

Returning to our concerns with Liang et al. (2016): how can such problems go unrecognised by authors, reviewers or editors in a high profile peer reviewed article? In particular, the simplistic causal inference? Part of the explanation may be prevalence and plausibility. Clearly, views can differ and-while we make no claim to be beyond such criticisms-we advocate less tolerance of causal claims based on plausibility. While correlations can be interesting and important we should be aware and explicit what we assume, infer and claim.

It is recognised in health and social sciences that elegant studies can gain undue prestige despite their failings (Ioannidis 2005; Smaldino and McElreath 2016; Camerer et al. 2018; Huebschmann et al. 2019). Our own numerous examples (e.g., Sheil 1995, 1996; Sheil et al. 1999, 2013, 2016, 2019; Sheil and Wunder 2002; Makarieva et al. 2014), and many others, suggest similar processes in other sciences including ecology, environment and climate. We all appreciate short, elegant articles but there is a cost to such simplification when key nuances and shortcomings are ignored or brushed aside. When presenting forest and biodiversity sciences to a wide readership we (authors, reviewers, editors and readers) must maintain our standards in terms of selfcritical framing and interpretation. We know that the relationships between diversity and productivity are likely to be complex-as indeed much of the debate over previous studies indicates (Huston 1997; Sandau et al. 2017; Wright et al. 2017; Fei et al. 2018). In such contexts, we should beware simplicity.

Despite our concerns, field observations remain valuable. While formal experiments are essential for controlling and clarifying many aspects of the diversityproductivity relationship for trees and forests, field observations offer additional insights.

Furthermore, our concerns about disturbance histories and successional influences can be addressed with a thorough evaluation of available data. For example, the influence of disturbance histories on forest diversity, productivity and other characteristics can be explored through permanent plots and other available data (see, e.g., Rozendaal and Chazdon 2015; Li et al. 2018; Scheuermann et al. 2018). Linking stand characteristics to known histories should also aid more general characterisation. The understanding available from such analyses when combined with field experiments and critical reflection offers further insights into forests communities and their values. In this sense, we support calls for a detailed and nuanced appraisal of how plant diversity contributes to biomass production and other ecosystem properties (Adair et al. 2018).

\section{Abbreviations \\ NPP: Net primary production; USD\$: United States Dollars}

Acknowledgements

We thank Jing Jing Liang, Robin Chazdon and three reviewers for useful feedback.

\section{Authors' contributions}

DS and FB jointly planned, drafted and finalised the text and figures. Both authors read and approved the final manuscript.

Authors' information

DS and FB are ecologists who focus on tropical forests.

Funding

DS's time was paid by the Norwegian University of Life Sciences. FB's time was paid by Wageningen University \& Research.

Availability of data and materials

Not applicable.

Ethics approval and consent to participate

Not applicable.

Consent for publication

Not applicable.

Competing interests

The authors declare that they have no competing interests.

\section{Author details}

${ }^{1}$ Faculty of Environmental Sciences and Natural Resource Management (MINA), Norwegian University of Life Sciences (NMBU), Box 5003, 1432 Ås, Norway. ${ }^{2}$ Forest Ecology and Forest Management Group, Wageningen University \& Research, PO Box 47, 6700 AA Wageningen, The Netherlands.

Received: 28 May 2019 Accepted: 9 January 2020

Published online: 31 January 2020

\section{References}

Adair EC, Hooper DU, Paquette A, Hungate BA (2018) Ecosystem context illuminates conflicting roles of plant diversity in carbon storage. Ecol Lett 21: 1604-1619

Arroyo-Rodríguez V, Melo FP, Martínez-Ramos M, Bongers F, Chazdon RL, Meave JA, Norden N, Santos BA, Leal IR, Tabarelli M (2017) Multiple successional pathways in human-modified tropical landscapes: new insights from forest succession, forest fragmentation and landscape ecology research. Biol Rev 92:326-340

Aubréville A (2015) In search of the forest in Côte d'Ivoire, parts 1 \& 2 (republished English translation of text originally presented in Bois et Forêts des Tropiques 1957 \& 1958). Bois et Forêts des Tropiques, pp 71-102

Bachelot B, Kobe RK (2013) Rare species advantage? Richness of damage types due to natural enemies increases with species abundance in a wet tropical forest. J Ecol 101:846-856 
Baker TR, Phillips OL, Malhi Y, Almeida S, Arroyo L, Di Fiore A, Erwin T, Killeen TJ, Laurance SG, Laurance WF, Lewis SL, Lloyd J, Monteagudo A, Neill DA, Patino S, Pitman NCA, Silva JNM, Martinez RV (2004) Variation in wood density determines spatial patterns in amazonian forest biomass. Glob Chang Biol 10: $545-562$

Barrett CB, Zhou M, Reich PB, Crowther TW, Liang J (2016) Forest value: more than commercial-response. Science 354:1541-1542

Beaudrot L, Kroetz K, Alvarez-Loayza P, Amaral I, Breuer T, Fletcher C, Jansen PA, Kenfack D, Lima MGM, Marshall AR, Martin EH, Ndoundou-Hockemba M, O'Brien T, Razafimahaimodison JC, Romero-Saltos H, Rovero F, Roy $\mathrm{CH}_{\text {, Sheil }}$ D, Silva CEF, Spironello WR, Valencia R, Zvoleff A, Ahumada J, Andelman S (2016) Limited carbon and biodiversity co-benefits for tropical forest mammals and birds. Ecol Appl 26:1098-1111

Bendix J, Wiley JJ, Commons MG (2017) Intermediate disturbance and patterns of species richness. Phys Geogr 38:393-403. https://doi.org/10.1080/02723646. 2017.1327269

Bongers F, Poorter L, Hawthorne WD, Sheil D (2009) The intermediate disturbance hypothesis applies to tropical forests, but disturbance contributes little to tree diversity. Ecol Lett 12:798-805. https://doi.org/10. 1111/j.1461-0248.2009.01329.x

Braat LC, de Groot R (2012) The ecosystem services agenda: bridging the worlds of natural science and economics, conservation and development, and public and private policy. Ecosyst Serv 1:4-15

Bruelheide H, Chen Y, Huang Y, Ma K, Niklaus PA, Schmid B (2019) Response to comment on "impacts of species richness on productivity in a large-scale subtropical forest experiment". Science 363:eaav9863. https://doi.org/10.1126/ science.aav9863

Camerer CF, Dreber A, Holzmeister F, Ho T-H, Huber J, Johannesson M, Kirchler M, Nave G, Nosek BA, Pfeiffer T, Altmejd A, Buttrick N, Chan T, Chen Y, Forsell E, Gampa A, Heikensten E, Hummer L, Imai T, Isaksson S, Manfredi D, Rose J, Wagenmakers E, Wu H (2018) Evaluating the replicability of social science experiments in nature and science between 2010 and 2015. Nat Hum Behav 2:637-644

Canham CD, LePage PT, Coates KD (2004) A neighborhood analysis of canopy tree competition: effects of shading versus crowding. Can J For Res 34:778-787

Chai SL, Tanner E (2011) 150-year legacy of land use on tree species composition in old-secondary forests of Jamaica. J Ecol 99:113-121

Chase JM, Leibold MA (2002) Spatial scale dictates the productivity-biodiversity relationship. Nature 416:427. https://doi.org/10.1038/416427a

Chave J, Condit R, Aguilar S, Hernandez A, Lao S, Perez R (2004) Error propagation and scaling for tropical forest biomass estimates. Philos Trans $R$ Soc Lon B Biol Sci 359:409-420

Chazdon RL (2003) Tropical forest recovery: legacies of human impact and natural disturbances. Persp Plant Ecol Evol Syst 6:51-71

Chazdon RL (2014) Second growth: the promise of tropical forest regeneration in an age of deforestation. University of Chicago Press, USA

Clark DA, Brown S, Kicklighter DW, Chambers JQ, Thomlinson JR, Ni J (2001a) Measuring net primary production in forests: concepts and field methods. Ecol Appl 11:356-370

Clark DA, Brown S, Kicklighter DW, Chambers JQ, Thomlinson JR, Ni J, Holland EA (2001b) Net primary production in tropical forests: an evaluation and synthesis of existing field data. Ecol Appl 11:371-384

Clark DA, Clark DB, Sandoval RM, Castro MVC (1995) Edaphic and human effects on landscape-scale distributions of tropical rain forest palms. Ecology 76 : $2581-2594$

Clements FE (1936) Nature and structure of the climax. J Ecol 24:252-284

Colwell RK, Chao A, Gotelli NJ, Lin S-Y, Mao CX, Chazdon RL, Longino JT (2012) Models and estimators linking individual-based and sample-based rarefaction, extrapolation and comparison of assemblages. J Plant Ecol 5:3-21

Connell JH (1978) Diversity in tropical rain forests and coral reefs - high diversity of trees and corals is maintained only in a non-equilibrium state. Science 199:1302-1310

Connell JH (1979) Tropical rain forests and coral reefs as open nonequilibrium systems. In: Anderson RM, Turner BD, Turner LR (eds) Population dynamics. British Ecological Society, UK, pp 141-163

Coomes DA, Kunstler G, Canham CD, Wright E (2009) A greater range of shadetolerance niches in nutrient-rich forests: an explanation for positive richnessproductivity relationships? J Ecol 97:705-717. https://doi.org/10.1111/j.13652745.2009.01507.x

Cox LA Jr (2018) Modernizing the Bradford Hill criteria for assessing causal relationships in observational data. Crit Rev Toxicol 48:682-712
Darwin C (1859) On the origin of species by means of natural selection. John Murray, London

Dawkins HC, Philip MS (1998) Tropical moist forest silviculture and management: a history of success and failure. CAB International, Oxford

del Río M, Pretzsch H, Ruíz-Peinado R, Ampoorter E, Annighöfer P, Barbeito I, Bielak K, Brazaitis G, Coll L, Drössler L, Fabrika M, Forrester DI, Heym M, Hurt V, Kurylyak V, Löf M, Lombardi F, Madrickiene E, Matović B, Mohren F, Motta R, den Ouden J, Pach M, Ponette Q, Schütze G, Skrzyszewski J, Sramek V, Sterba H, Stojanović D, Svoboda M, Zlatanov TM, Bravo-Oviedo A, Drössler L (2017) Species interactions increase the temporal stability of community productivity in Pinus sylvestris-Fagus sylvatica mixtures across europe. J Ecol 105:1032-1043

Ding Y, Zang R, Liu S, He F, Letcher SG (2012) Recovery of woody plant diversity in tropical rain forests in southern China after logging and shifting cultivation. Biol Conserv 145:225-233

Dormann CF, Schneider H, Gorges J (2019) Neither global nor consistent: a technical comment on the tree diversity-productivity analysis of Liang et al. (2016). BioRxiv (online):34

Doucet J-L, Kouadio YL, Monticelli D, Lejeune P (2009) Enrichment of logging gaps with moabi (Baillonella toxisperma Pierre) in a Central African rain forest. Forest Ecol Manag 258:2407-2415

Drake JE, Davis SC, Raetz LM, DeLucia EH (2011) Mechanisms of age-related changes in forest production: the influence of physiological and successional changes. Glob Chang Biol 17:1522-1535. https://doi.org/10.1111/j.1365-2486. 2010.02342.x

Duivenvoorden J (1996) Patterns of tree species richness in rain forests of the middle Caqueta area, Columbia, NW Amazonia. Biotropica 28:142-158

Edwards DP, Tobias JA, Sheil D, Meijaard E, Laurance WF (2014) Maintaining ecosystem function and services in logged tropical forests. Trend Ecol Evol 29:511-520

Eggeling WJ (1947) Observations on the ecology of the Budongo rain forest, Uganda. J Ecol 34:20-87

Fanin N, Gundale MJ, Farrell M, Ciobanu M, Baldock JA, Nilsson M-C, Kardol P, Wardle DA (2018) Consistent effects of biodiversity loss on multifunctionality across contrasting ecosystems. Nat Ecol Evol 2:269-278. https://doi.org/10. 1038/s41559-017-0415-0

Fei S, Jo I, Guo Q, Wardle DA, Fang J, Chen A, Oswalt CM, Brockerhoff EG (2018) Impacts of climate on the biodiversity-productivity relationship in natural forests. Nat Commun 9:5436. https://doi.org/10.1038/s41467-018-07880-w

Fichtner A, Härdtle W, Li Y, Bruelheide H, Kunz M, von Oheimb G (2017) From competition to facilitation: how tree species respond to neighbourhood diversity. Ecol Lett 20:892-900. https://doi.org/10.1111/ele.12786

Fox JW (2013b) The intermediate disturbance hypothesis is broadly defined, substantive issues are key: a reply to Sheil and Burslem. Trend Ecol Evol 28: $572-573$

Fox JW (2013a) The intermediate disturbance hypothesis should be abandoned. Trend Ecol Evol 28:86-92

Freedman DA (2006) Statistical models for causation: what inferential leverage do they provide? Eval Rev 30:691-713

Gamfeldt L, Snäll T, Bagchi R, Jonsson M, Gustafsson L, Kjellander P, Ruiz-Jaen MC, Fröberg M, Stendahl J, Philipson CD (2013) Higher levels of multiple ecosystem services are found in forests with more tree species. Nat Commun 4:1340

Guariguata MR, Ostertag R (2001) Neotropical secondary forest succession: changes in structural and functional characteristics. Forest Ecol Manag 148: 185-206

Ghazoul J, Sheil D (2010) Tropical rain forests ecology, diversity and conservation. Oxford University Press, Oxford, UK

Gleason HA (1917) The structure and development of the plant association. Bull Torrey Bot Club 44:463-481

Gough CM, Curtis PS, Hardiman BS, Scheuermann CM, Bond-Lamberty B (2016) Disturbance, complexity, and succession of net ecosystem production in North America's temperate deciduous forests. Ecosphere 7:e01375-n/a. https://doi.org/10.1002/ecs2.1375

Goulden ML, McMillan A, Winston G, Rocha A, Manies K, Harden JW, BondLamberty B (2011) Patterns of NPP, GPP, respiration, and NEP during boreal forest succession. Glob Chang Biol 17:855-871

Grace JB, Anderson TM, Seabloom EW, Borer ET, Adler PB, Harpole WS, Hautier Y, Hillebrand H, Lind EM, Pärtel M, Bakker JD, Buckley YM, Crawley MJ, Damschen El, Davies KF, Fay PA, Firn J, Gruner DS, Hector A, Knops JMH, MacDougall AS, Melbourne BA, Morgan JW, Orrock JL, Prober SM, Smith MD 
(2016) Integrative modelling reveals mechanisms linking productivity and plant species richness. Nature 529:390. https://doi.org/10.1038/nature16524

Greig-Smith P (1952) Ecological observations on degraded and secondary forest in Trinidad, British West Indies: I General features of the vegetation. J Ecol 40: 283-315

Harrison P, Berry P, Simpson G, Haslett J, Blicharska M, Bucur M, Dunford R, Egoh B, Garcia-Llorente M, Geamănă N (2014) Linkages between biodiversity attributes and ecosystem services: a systematic review. Ecosyst Serv 9:191203

He L, Chen JM, Pan Y, Birdsey R, Kattge J (2012) Relationships between net primary productivity and forest stand age in U.S. forests. Global Biogeochem Cycl 26. https://doi.org/10.1029/2010GB003942

Hector A (1998) The effect of diversity on productivity: detecting the role of species complementarity. Oikos:597-599

Hewetson C (1956) A discussion on the "climax" concept in relation to the tropical rain and deciduous forest. Empire For Rev:274-291

Höfer T, Przyrembel H, Verleger S (2004) New evidence for the theory of the stork. Paediatr Perinat Epidemiol 18:88-92. https://doi.org/10.1111/j.13653016.2003.00534x

Holland PW (1986) Statistics and causal inference. J Am Stat Assoc 81:945-960

Huang Y, Chen Y, Castro-Izaguirre N, Baruffol M, Brezzi M, Lang A, Li Y, Härdtle W, von Oheimb G, Yang X (2018) Impacts of species richness on productivity in a large-scale subtropical forest experiment. Science 362:80-83

Huebschmann AG, Leavitt IM, Glasgow RE (2019) Making health research matter: a call to increase attention to external validity. Annu Rev Public Health 40:45-63

Hurlbert SH (1971) The non-concept of species diversity: a critique and alternative parameters. Ecology 52:577-586

Huston MA (1994) Biological diversity: the coexistence of species on changing landscapes. Cambridge University Press, Cambridge

Huston MA (1997) Hidden treatments in ecological experiments: re-evaluating the ecosystem function of biodiversity. Oecologia 110:449-460

Huston MA (2014) Disturbance, productivity, and species diversity: empiricism versus logic in ecological theory. Ecology 95:2382-2396

Huston MA, Aarssen LW, Austin MP, Cade BS, Fridley JD, Garnier E, Grime JP, Hodgson J, Lauenroth WK, Thompson K, Vandermeer JH, Wardle DA (2000) No consistent effect of plant diversity on productivity. Science 289:1255a1255. doi: https://doi.org/10.1126/science.289.5483.1255a

loannidis JP (2005) Why most published research findings are false. PLOS Med 2: e124

Jucker T, Avăcăriței D, Bărnoaiea I, Duduman G, Bouriaud O, Coomes DA (2016) Climate modulates the effects of tree diversity on forest productivity. J Ecol 104:388-398

Jucker T, Bongalov B, Burslem DFRP, Nilus R, Dalponte M, Lewis SL, Phillips OL, Qie L, Coomes DA (2018) Topography shapes the structure, composition and function of tropical forest landscapes. Ecol Lett 21:989-1000. https://doi.org/ 10.1111/ele.12964

Jucker T, Bouriaud O, Avacaritei D, Coomes DA (2014a) Stabilizing effects of diversity on aboveground wood production in forest ecosystems: linking patterns and processes. Ecol Lett 17:1560-1569

Jucker T, Bouriaud O, Avacaritei D, Dănilă I, Duduman G, Valladares F, Coomes DA (2014b) Competition for light and water play contrasting roles in driving diversity-productivity relationships in Iberian forests. J Ecol 102:1202-1213

Jucker T, Bouriaud O, Coomes DA (2015) Crown plasticity enables trees to optimize canopy packing in mixed-species forests. Funct Ecol 29:1078-1086

Kaufmann MR, Ryan MG (1986) Physiographic, stand, and environmental effects on individual tree growth and growth efficiency in subalpine forests. Tree Physiol 2:47-59

Kershaw HM, Mallik AU (2013) Predicting plant diversity response to disturbance: applicability of the intermediate disturbance hypothesis and mass ratio hypothesis. Crit Rev Plant Sci 32:383-395

King DA, Davies SJ, Tan S, Noor NS (2006) The role of wood density and stem support costs in the growth and mortality of tropical trees. J Ecol 94:670-680

Kohyama TS, Kohyama TI, Sheil D (2019) Estimating net biomass production and loss from repeated measurements of trees in forests and woodlands: formulae, biases and recommendations. Forest Ecol Manag 433:729-740

LaManna JA, Walton ML, Turner BL, Myers JA (2016) Negative density dependence is stronger in resource-rich environments and diversifies communities when stronger for common but not rare species. Ecol Lett 19:657-667

Langford AN, Buell MF (1969) Integration, identity and stability in the plant association. Adv Ecol Res 6:83-135. https://doi.org/10.1016/S00652504(08)60257-3
Lasky JR, Uriarte M, Boukili VK, Erickson DL, Kress JW, Chazdon RL (2014) The relationship between tree biodiversity and biomass dynamics changes with tropical forest succession. Ecol Lett 17:1158-1167

Leuschner C, Jungkunst HF, Fleck S (2009) Functional role of forest diversity: pros and cons of synthetic stands and across-site comparisons in established forests. Basic Appl Ecol 10:1-9

Li S, Su J, Lang X, Liu W, Ou G (2018) Positive relationship between species richness and aboveground biomass across forest strata in a primary Pinus kesiya forest. Sci Rep 8:2227. https://doi.org/10.1038/s41598-018-20165-y

Liang J, Buongiorno J, Monserud RA (2005) Growth and yield of all-aged Douglas-fir western hemlock forest stands: a matrix model with stand diversity effects. Can J For Res 35:2368-2381

Liang J, Buongiorno J, Monserud RA, Kruger EL, Zhou M (2007) Effects of diversity of tree species and size on forest basal area growth, recruitment, and mortality. Forest Ecol Manag 243:116-127

Liang J, Crowther TW, Picard N, Wiser S, Zhou M, Alberti G, Schulze E-D, McGuire $A D$, Bozzato $F$, Pretzsch $H$, de- Miquel S, Paquette A, Hérault B, SchererLorenzen M, Barrett CB, Glick HB, Hengeveld GM, Nabuurs G-J, Pfautsch S, Viana H, Vibrans AC, Ammer C, Schall P, Verbyla D, Tchebakova N, Fischer M, Watson JV, HYH C, Lei X, Schelhaas M-J, Lu H, Gianelle D, Parfenova El, Salas C, Lee E, Lee B, Kim HS, Bruelheide H, Coomes DA, Piotto D, Sunderland T, Schmid B, Gourlet-Fleury S, Sonké B, Tavani R, Zhu J, Brandl S, Vayreda J, Kitahara F, Searle EB, Neldner VJ, Ngugi MR, Baraloto C, Frizzera L, Bałazy R, Oleksyn J, Zawiła-Niedźwiecki T, Bouriaud O, Bussotti F, Finér L, Jaroszewicz B, Jucker T, Valladares F, Jagodzinski AM, Peri PL, Gonmadje C, Marthy W, O'Brien T, Martin EH, Marshall AR, Rovero F, Bitariho R, Niklaus PA, AlvarezLoayza P, Chamuya N, Valencia R, Mortier F, Wortel V, Engone-Obiang NL, Ferreira LV, Odeke DE, Vasquez RM, Lewis SL, Reich PB (2016) Positive biodiversity-productivity relationship predominant in global forests. Science 354:aaf8957. https://doi.org/10.1126/science.aaf8957

Liira J, Sepp T, Parrest O (2007) The forest structure and ecosystem quality in conditions of anthropogenic disturbance along productivity gradient. Forest Ecol Manag 250:34-46

Litton CM, Raich JW, Ryan MG (2007) Carbon allocation in forest ecosystems. Glob Chang Biol 13:2089-2109

Lohbeck M, Poorter L, Martínez-Ramos M, Bongers F (2015) Biomass is the main driver of changes in ecosystem process rates during tropical forest succession. Ecology 96:1242-1252

Loreau M, Naeem S, Inchausti P, Bengtsson J, Grime J, Hector A, Hooper D, Huston M, Raffaelli D, Schmid B (2001) Biodiversity and ecosystem functioning: current knowledge and future challenges. Science 294:804-808

Lorenz K, Lal R (2010) Carbon sequestration in forest ecosystems. Springer, Netherlands

Lu H, Condés S, del Río M, Goudiaby V, den Ouden J, Mohren GM, Schelhaas M-J, de Waal R, Sterck FJ (2018) Species and soil effects on overyielding of tree species mixtures in the Netherlands. Forest Ecol Manag 409:105-118

Luo W, Liang J, Gatti RC, Zhao X, Zhang C (2019) Parameterization of biodiversity-productivity relationship and its scale dependency using georeferenced tree-level data. J Ecol 107:1106-1119

Makarieva AM, Gorshkov VG, Sheil D, Nobre AD, Bunyard P, Li B-L (2014) Why does air passage over forest yield more rain? Examining the coupling between rainfall, pressure, and atmospheric moisture content. J Hydrometeorol 15:411-426

Malhi Y (2012) The productivity, metabolism and carbon cycle of tropical forest vegetation. J Ecol 100:65-75

Mangan SA, Schnitzer SA, Herre EA, Mack KM, Valencia MC, Sanchez El, Bever JD (2010) Negative plant-soil feedback predicts tree-species relative abundance in a tropical forest. Nature $466: 752$

Martin PA, Newton AC, Bullock JM (2013) Carbon pools recover more quickly than plant biodiversity in tropical secondary forests. Proc R Soc B. https://doi. org/10.1098/rspb.2013.2236

MEA-team (2005) Millennium Ecosystem Assessment: ecosystems and human well-being (synthesis). Island Press, Washington, DC

Medjibe VP, Putz FE, Starkey MP, Ndouna AA, Memiaghe HR (2011) Impacts of selective logging on above-ground forest biomass in the Monts de Cristal in Gabon. Forest Ecol Manag 262:1799-1806

Mencuccini M, Martínez-Vilalta J, Vanderklein D, Hamid H, Korakaki E, Lee S, Michiels B (2005) Size-mediated ageing reduces vigour in trees. Ecol Lett 8:1183-1190

Michaletz ST, Cheng D, Kerkhoff AJ, Enquist BJ (2014) Convergence of terrestrial plant production across global climate gradients. Nature 512:39-43. https:// doi.org/10.1038/nature13470 
Molino JF, Sabatier D (2001) Tree diversity in tropical rain forests: a validation of the intermediate disturbance hypothesis. Science 294:1702-1704

Mori AS (2018) Environmental controls on the causes and functional consequences of tree species diversity. J Ecol 106:113-125

Mori AS, Lertzman KP, Gustafsson L (2017) Biodiversity and ecosystem services in forest ecosystems: a research agenda for applied forest ecology. J Appl Ecol 54:12-27

Nadrowski K, Wirth C, Scherer-Lorenzen M (2010) Is forest diversity driving ecosystem function and service? Curr Opin Environ Sust 2:75-79

Naeem S, Thompson LJ, Lawler SP, Lawton JH, Woodfin RM (1994) Declining biodiversity can alter the performance of ecosystems. Nature 368:734

Nepstad DC, Tohver IM, Ray D, Moutinho P, Cardinot G (2007) Mortality of large trees and lianas following experimental drought in an Amazon forest. Ecology 88:2259-2269

Niinemets Ü, Sparrow A, Cescatti A (2005) Light capture efficiency decreases with increasing tree age and size in the southern hemisphere gymnosperm Agathis australis. Trees 19:177-190

Nock C, Caspersen J, Thomas S (2008) Large ontogenetic declines in intra-crown leaf area index in two temperate deciduous tree species. Ecology 89:744-753

Norden N, Angarita HA, Bongers F, Martínez-Ramos M, Granzow-de la Cerda I, van Breugel M, Lebrija-Trejos E, Meave JA, Vandermeer J, Williamson GB (2015) Successional dynamics in neotropical forests are as uncertain as they are predictable. PNAS 112:8013-8018

Norden N, Mesquita RC, Bentos TV, Chazdon RL, Williamson GB (2011) Contrasting community compensatory trends in alternative successional pathways in Central Amazonia. Oikos 120:143-151

Oram NJ, Ravenek JM, Barry KE, Weigelt A, Chen H, Gessler A, Gockele A, Kroon H, Paauw JW, Scherer-Lorenzen M (2018) Below-ground complementarity effects in a grassland biodiversity experiment are related to deep-rooting species. J Ecol 106:265-277

Paul C, Knoke T (2016) Forest value: more than commercial. Science 354:1541-1541

Pearl J (2018) Does obesity shorten life? Or is it the soda? On non-manipulable causes. J Caus Infer 6. https://doi.org/10.1515/jci-2018-2001

Peña-Claros M, Peters E, Justiniano M, Bongers F, Blate GM, Fredericksen T, Putz F (2008) Regeneration of commercial tree species following silvicultural treatments in a moist tropical forest. Forest Ecol Manag 255:1283-1293

Phillips J (1934) Succession, development, the climax, and the complex organism: an analysis of concepts. Part I J Ecol 22:554-571

Plumptre R (1996) Links between utilisation, product marketing and forest management in tropical moist forest. Commonwealth For Rev:316-324

Plumptre R, Earl D (1986) Integrating small industries with management of tropical forest for improved utilisation and higher future productivity. J World For Res Manag 2:43-55

Poorter L, Bongers F, Aide TM, Almeyda Zambrano AM, Balvanera P, Becknell JM, Boukili V, Brancalion PHS, Broadbent EN, Chazdon RL, Craven D, de AlmeidaCortez JS, Cabral GAL, de Jong BHJ, Denslow JS, Dent DH, DeWalt SJ, Dupuy JM, Durán SM, Espírito-Santo MM, Fandino MC, César RG, Hall JS, HernandezStefanoni JL, Jakovac CC, Junqueira AB, Kennard D, Letcher SG, Licona J-C, Lohbeck M, Marín-Spiotta E, Martínez-Ramos M, Massoca P, Meave JA, Mesquita R, Mora F, Muñoz R, Muscarella R, Nunes YRF, Ochoa-Gaona S, de Oliveira AA, Orihuela-Belmonte E, Peña-Claros M, Pérez-García EA, Piotto D, Powers JS, Rodríguez-Velázquez J, Romero-Pérez IE, Ruíz J, Saldarriaga JG, Sanchez-Azofeifa A, Schwartz NB, Steininger MK, Swenson NG, Toledo M, Uriarte $M$, van Breugel $M$, van der Wal H, Veloso MDM, Vester HFM, Vicentini A, Vieira ICG, Bentos TV, Williamson GB, Rozendaal DMA (2016) Biomass resilience of Neotropical secondary forests. Nature 530:211-214.

Poorter L, Rozendaal DMA, Bongers F, de Almeida-Cortez JS, Almeyda Zambrano AM, Álvarez FS, Andrade JL, Villa LFA, Balvanera P, Becknell JM, Bentos TV, Bhaskar R, Boukili V, Brancalion PHS, Broadbent EN, César RG, Chave J, Chazdon RL, Colletta GD, Craven D, de Jong BHJ, Denslow JS, Dent DH, DeWalt SJ, García ED, Dupuy JM, Durán SM, Espírito Santo MM, Fandiño MC, Fernandes GW, Finegan B, Moser VG, Hall JS, Hernández-Stefanoni JL, Jakovac CC, Junqueira AB, Kennard D, Lebrija-Trejos E, Letcher SG, Lohbeck M, Lopez OR, Marín-Spiotta E, Martínez-Ramos M, Martins SV, Massoca PES, Meave JA, Mesquita R, Mora F, de Souza MV, Müller SC, Muñoz R, Muscarella R, de Oliveira Neto SN, Nunes YRF, Ochoa-Gaona S, Paz H, Peña-Claros M, Piotto D, Ruíz J, Sanaphre-Villanueva L, Sanchez-Azofeifa A, Schwartz NB, Steininger MK, Thomas WW, Toledo M, Uriarte M, Utrera LP, van Breugel M, van der Sande MT, van der Wal H, Veloso MDM, Vester HFM, Vieira ICG, Villa PM, Williamson GB, Wright SJ, Zanini KJ Zimmerman JK, Westoby M (2019) Wet and dry tropical forests show opposite successional pathways in wood density but converge over time. Nature Ecol Evol. https://doi.org/10.1038/s41559-019-0882-6
Praciak A, Pasiecznik N, Sheil D, van Heist M, Sassen M, Correia CS, Dixon C, Fyson G, Rushforth K, Teeling C (2013) The CABI encyclopedia of forest trees. CABI, Wallingford

Prado-Junior JA, Schiavini I, Vale VS, Arantes CS, van der Sande MT, Lohbeck M, Poorter $L$ (2016) Conservative species drive biomass productivity in tropical dry forests. J Ecol 104:817-827. https://doi.org/10.1111/1365-2745.12543

Quinn EM, Thomas SC (2015) Age-related crown thinning in tropical forest trees. Biotropica 47:320-329

Richards P (1952) The tropical rain forest: an ecological study. Cambridge University Press, Cambridge, UK

Richards PW (1939) Ecological studies on the rain forest of southern Nigeria: I. The structure and floristic composition of the primary forest. J Ecol 27:1-61

Roxburgh S, Berry SL, Buckley T, Barnes B, Roderick M (2005) What is NPP? Inconsistent accounting of respiratory fluxes in the definition of net primary production. Funct Ecol 19:378-382

Royo AA, Carson WP (2006) On the formation of dense understory layers in forests worldwide: consequences and implications for forest dynamics, biodiversity, and succession. Can J Forest Res-Revue Canadienne De Recherche Forestiere 36:1345-1362

Rozendaal DM, Chazdon RL, Arreola-Villa F, Balvanera P, Bentos TV, Dupuy JM, Hernández-Stefanoni JL, Jakovac CC, Lebrija-Trejos EE, Lohbeck M, MartínezRamos M, Massoca PES, Meave JA, Mesquita RCG, Mora F, Pérez-García EA, Romero-Pérez IE, Saenz-Pedroza I, van Breugel M, Williamson GB, Bongers F (2016) Demographic drivers of aboveground biomass dynamics during secondary succession in neotropical dry and wet forests. Ecosystems 20:1-14

Rozendaal DMA, Bongers F, Aide TM, Alvarez-Dávila E, Ascarrunz N, Balvanera P, Becknell JM, Bentos TV, Brancalion PHS, Cabral GAL, Calvo-Rodriguez S, Chave J, César RG, Chazdon RL, Condit R, Dallinga JS, de Almeida-Cortez JS, de Jong B, de Oliveira A, Denslow JS, Dent DH, DeWalt SJ, Dupuy JM, Durán SM, Dutrieux LP, Espírito-Santo MM, Fandino MC, Fernandes GW, Finegan B, García H, Gonzalez N, Moser VG, Hall JS, Hernández-Stefanoni JL, Hubbell S, Jakovac CC, Hernández AJ, Junqueira AB, Kennard D, Larpin D, Letcher SG, Licona J-C, Lebrija-Trejos E, Marín-Spiotta E, Martínez-Ramos M, Massoca PES, Meave JA, Mesquita RCG, Mora F, Müller SC, Muñoz R, de Oliveira Neto SN, Norden N, Nunes YRF, Ochoa-Gaona S, Ortiz-Malavassi E, Ostertag R, PeñaClaros M, Pérez-García EA, Piotto D, Powers JS, Aguilar-Cano J, RodriguezBuritica S, Rodríguez-Velázquez J, Romero-Romero MA, Ruíz J, SanchezAzofeifa A, de Almeida AS, Silver WL, Schwartz NB, Thomas WW, Toledo M, Uriarte M, de Sá Sampaio EV, van Breugel M, van der Wal H, Martins SV, Veloso MDM, Vester HFM, Vicentini A, Vieira ICG, Villa P, Williamson GB, Zanini KJ, Zimmerman J, Poorter L (2019) Biodiversity recovery of neotropical secondary forests. Sci Adv 5:eaau3114. https://doi.org/10.1126/sciadv.aau3114

Rozendaal DMA, Chazdon RL (2015) Demographic drivers of tree biomass change during secondary succession in northeastern Costa Rica. Ecol Appl 25:506-516. https://doi.org/10.1890/14-0054.1

Sandau N, Fabian Y, Bruggisser OT, Rohr RP, Naisbit RE, Kehrli P, Aebi A, Bersier LF (2017) The relative contributions of species richness and species composition to ecosystem functioning. Oikos 126:782-791

Scheuermann CM, Nave LE, Fahey RT, Nadelhoffer KJ, Gough CM (2018) Effects of canopy structure and species diversity on primary production in upper great lakes forests. Oecologia 188:405-415. https://doi.org/10.1007/s00442-018-4236-x

Searle EB, Chen HY (2017) Tree size thresholds produce biased estimates of forest biomass dynamics. Forest Ecol Manag 400:468-474

Seidl R, Fernandes PM, Fonseca TF, Gillet F, Jönsson AM, Merganičovák NS, Arpac A, Bontemps J-D, Bugmann H (2011) Modelling natural disturbances in forest ecosystems: a review. Ecol Model 222:903-924

Sheil D (1995a) A critique of permanent plot methods and analysis with examples from Budongo-forest, Uganda. Forest Ecol Manag 77:11-34

Sheil D (1995b) Evaluating turnover in tropical forests. Science 268:894-894

Sheil D (1996) Species richness, tropical forest dynamics and sampling: questioning cause and effect. Oikos 76:587-590

Sheil D (2016) Disturbance and distributions: avoiding exclusion in a warming world. Ecol Soc 21:10 (online)

Sheil D, Bargués-Tobella A, llstedt U, Ibisch PL, Makarieva A, McAlpine C, Morris CE, Murdiyarso D, Nobre AD, Poveda G, Spracklen DV, Sullivan CA, Tuinenburg OA, van der Ent RJ (2019) Forest restoration: Transformative trees. Science 366:316-317

Sheil D, Burslem D (2003) Disturbing hypotheses in tropical forests. Trend Ecol Evol 18:18-26

Sheil D, Burslem D (2013) Defining and defending Connell's intermediate disturbance hypothesis: a response to Fox. Trend Ecol Evol 28:571-572 
Sheil D, Eastaugh CS, Vlam M, Zuidema PA, Groenendijk P, der Sleen P, Jay A, Vanclay J (2016) Does biomass growth increase in the largest trees?-flaws, fallacies, and alternative analyses. Funct Ecol 31:568-581

Sheil D, Meijaard E, Angelsen A, Sayer J, Vanclay JK (2013) Sharing future conservation costs. Science 339:270-271

Sheil D, Sayer JA, O'Brien TJS (1999) Tree species diversity in logged rainforests. Science 284:1587-1587

Sheil D, Wunder S (2002) The value of tropical forest to local communities: complications, caveats, and cautions. Conserv Ecol 6(2):22

Sileshi GW (2014) A critical review of forest biomass estimation models, common mistakes and corrective measures. Forest Ecol Manag 329:237-254

Šímová I, Storch D (2017) The enigma of terrestrial primary productivity: measurements, models, scales and the diversity-productivity relationship. Ecography 40:239-252. https://doi.org/10.1111/ecog.02482

Slik JWF, Bernard CS, Breman FC, Van Beek M, Salim A, Sheil D (2008) Wood density as a conservation tool: quantification of disturbance and identification of conservation-priority areas in tropical forests. Conserv Biol 22:1299-1308

Smaldino PE, McElreath R (2016) The natural selection of bad science. Roy Soc Open Sci 3:160384

Snook LK (1996) Catastrophic disturbance, logging and the ecology of mahogany (Swietenia macrophylla King): grounds for listing a major tropical timber species in cites. Bot J Linn Soc 122:35-46

Ssali F, Moe SR, Sheil D (2017) A first look at the impediments to forest recovery in bracken-dominated clearings in the African highlands. Forest Ecol Manag 402:166-176

Sullivan MJP, Talbot J, Lewis SL, Phillips OL, Qie L, Begne SK, Chave J, CuniSanchez A, Hubau W, Lopez-Gonzalez G, Miles L, Monteagudo-Mendoza A, SonkéB ST, ter Steege H, White LJT, Affum-Baffoe K, S-i A, de Almeida EC, de Oliveira EA, Alvarez-Loayza P, Dávila EÁ, Andrade A, Aragão LEOC, Ashton P, Aymard CGA, Baker TR, Balinga M, Banin LF, Baraloto C, Bastin J-F, Berry N, Bogaert J, Bonal D, Bongers F, Brienen R, Camargo JLC, Cerón C, Moscoso VC, Chezeaux E, Clark CJ, Pacheco ÁC, Comiskey JA, Valverde FC, Coronado ENH, Dargie G, Davies SJ, De Canniere C, Djuikouo KMN, Doucet J-L, Erwin TL, Espejo JS, Ewango CEN, Fauset S, Feldpausch TR, Herrera R, Gilpin M, Gloor E, Hall JS, Harris DJ, Hart TB, Kartawinata K, Kho LK, Kitayama K, Laurance SGW, Laurance WF, Leal ME, Lovejoy T, Lovett JC, Lukasu FM, Makana J-R, Malhi Y, Maracahipes L, Marimon BS, Junior BHM, Marshall AR, Morandi PS, Mukendi JT, Mukinzi J, Nilus R, Vargas PN, Camacho NCP, Pardo G, Peña-Claros M, Pétronelli $P$, Pickavance GC, Poulsen AD, Poulsen JR, Primack RB, Priyadi $H$, Quesada CA, Reitsma J, Réjou-Méchain M, Restrepo Z, Rutishauser E, Salim KA, Salomão RP, Samsoedin I, Sheil D, Sierra R, Silveira M, Slik JWF, Steel L, Taedoumg H, Tan S, Terborgh JW, Thomas SC, Toledo M, Umunay PM, Gamarra LV, Vieira ICG, Vos VA, Wang O, Willcock S, Zemagho L (2017) Diversity and carbon storage across the tropical forest biome. Sci Rep 7: 39102. https://doi.org/10.1038/srep39102

Swenson NG, Enquist BJ (2007) Ecological and evolutionary determinants of a key plant functional trait: wood density and its community-wide variation across latitude and elevation. Am J Bot 94:451-459

Talbot J, Lewis SL, Lopez-Gonzalez G, Brienen RJ, Monteagudo A, Baker TR, Feldpausch TR, Malhi Y, Vanderwel M, Murakami AA (2014) Methods to estimate aboveground wood productivity from long-term forest inventory plots. Forest Ecol Manag 320:30-38

Tansley AG (1920) The classification of vegetation and the concept of development. J Ecol:118-149

Ter Steege H, Hammond DS (2001) Character convergence, diversity, and disturbance in tropical rain forest in Guyana. Ecology 82:3197-3212

Thomas SC (2010) Photosynthetic capacity peaks at intermediate size in temperate deciduous trees. Tree Physiol 30(5):555-573

Tilman D (1982) Resource competition and community structure. Princeton University Press, New Jersey

Tilman D, Wedin D, Knops J (1996) Productivity and sustainability influenced by biodiversity in grassland ecosystems. Nature 379:718

Tobner CM, Paquette A, Gravel D, Reich PB, Williams LJ, Messier C (2016) Functional identity is the main driver of diversity effects in young tree communities. Ecol Lett 19:638-647

Transeau EN (1908) The relation of plant societies to evaporation. Bot Gazett 45: 217-231

Tymen B, Réjou-Méchain M, Dalling JW, Fauset S, Feldpausch TR, Norden N, Phillips OL, Turner BL, Viers J, Chave J (2016) Evidence for arrested succession in a liana-infested Amazonian forest. J Ecol 104:149-159 van Nieuwstadt MGL, Sheil D (2005) Drought, fire and tree survival in a Borneo rain forest, East Kalimantan, Indonesia. J Ecol 93:191-201

Verheyen K, Vanhellemont M, Auge H, Baeten L, Baraloto C, Barsoum N, BilodeauGauthier S, Bruelheide H, Castagneyrol B, Godbold D, Haase J, Hector A, Jactel H, Koricheva J, Loreau M, Mereu S, Messier C, Muys B, Nolet P, Paquette A, Parker J, Perring M, Ponette Q, Potvin C, Reich P, Smith A, Weih M, Scherer-Lorenzen M (2016) Contributions of a global network of tree diversity experiments to sustainable forest plantations. Ambio 45:29-41

Waide R, Willig M, Steiner C, Mittelbach G, Gough L, Dodson S, Juday G, Parmenter R (1999) The relationship between productivity and species richness. Annu Rev Ecol Syst 30:257-300

Wang X, Wiegand T, Kraft NJ, Swenson NG, Davies SJ, Hao Z, Howe R, Lin Y, Ma K, Mi X (2016) Stochastic dilution effects weaken deterministic effects of niche-based processes in species rich forests. Ecology 97:347-360

Wardle DA (2001) No observational evidence for diversity enhancing productivity in Mediterranean shrublands. Oecologia 129:620-621

Waring R, Landsberg J, Williams M (1998) Net primary production of forests: a constant fraction of gross primary production? Tree Physiol 18:129-134

Watt AS (1947) Pattern and process in the plant community. J Ecol 35:1-22

Webb L (1958) Cyclones as an ecological factor in tropical lowland rain-forest, North Queensland. Austr J Bot 6:220-228

Whittaker RJ, Jones SH, Partomihardjo T (1997) The rebuilding of an isolated rain forest assemblage: how disharmonic is the flora of Krakatau? Biodivers Conserv 6:1671-1696

Williams LJ, Paquette A, Cavender-Bares J, Messier C, Reich PB (2017) Spatial complementarity in tree crowns explains overyielding in species mixtures. Nat Ecol Evol 1:0063

Williams M, Schwarz PA, Law BE, Irvine J, Kurpius MR (2005) An improved analysis of forest carbon dynamics using data assimilation. Glob Chang Biol 11:89-105

Wright AJ, Wardle DA, Callaway R, Gaxiola A (2017) The overlooked role of facilitation in biodiversity experiments. Trend Ecol Evol 32:383-390. https:// doi.org/10.1016/j.tree.2017.02.011

Yang Y, Saatchi SS, Xu L, Yu Y, Lefsky MA, White L, Knyazikhin Y, Myneni RB (2016) Abiotic controls on macroscale variations of humid tropical forest height. Remote Sens 8:494

Yoder B, Ryan M, Waring R, Schoettle A, Kaufmann M (1994) Evidence of reduced photosynthetic rates in old trees. For Sci 40:513-527

\section{Submit your manuscript to a SpringerOpen ${ }^{\circ}$ journal and benefit from:}

- Convenient online submission

- Rigorous peer review

- Open access: articles freely available online

- High visibility within the field

- Retaining the copyright to your article

Submit your next manuscript at $>$ springeropen.com 